those young people who wish to stay on voluntarily at school beyond the minimum school-leaving age and there is nothing in the White Paper about fixing dates for measures to extend the compulsory period of education. The programme is part of a concerted drive to create an educational system adequate to meet both national and individual needs in the modern world. The keynote is opportunity for the individual boy or girl to go as far as his or her keenness or ability will allow, and the nation must grasp the opportunity to develop the educational system so that it can better fulfil its task of producing citizens who are fitted by character, knowledge and skill to play their full part in an increasingly educated and responsible democratic society.

Before outlining the specifie programme, the White Paper points out that the Government does not wish to rule out experiments with comprehensive or similar schools proposed on genuine educational grounds, but is convinced that it would be wrong to abandon the grammar schools, though they alone cannot provide sufficient numbers of highly trained citizens. There is still plenty of room for experiment in the precise pattern of organization to be adopted. The widest possible range of opportunities should be provided for boys and girls of different capacities and fitness, but it is wrong to think that each school can do everything or that each type of school must have a fixed and self-contained exclusive territory.

As a first step the Government proposes to launch and carry through a continuous building programme for primary and secondary schools, rising from $\$ 55$ million in 1960-61 to about $f 60$ million in 1961-62 and costing $£ 300$ million in the five years to $1964-65$. An immediate increase is being made in the volume of minor works which local education authorities and school governors can undertake, and the limit of cost is being raised from $£ 10,000$ to $£ 20,000$. The reorganization of the remaining 'all-age schools' in which are more than 150,000 pupils of eleven or more is to be completed, and resources will also be found for improving conditions in existing secondary schools. Reference is made to the improvement of science facilities, and although it is not expected to bring all secondary school buildings up to modern standards, by concentrating first on the tasks that will most quickly yield improvements it is hoped to make a big advance towards secondary education for all within the five-year programme. As regards the reduction in the size of classes, the Government's policy is first to increase the supply of teachers, and apart from the expansion of teacher training colleges already announced the Government's policy is to increase recruitment from universities also as far as is consistent with the maintenance and improvement of quality. It is determined that the size of primary classes should continue to be reduced as quickly as possible so that classes of more than forty children are virtually eliminated by the middle-1960's. A decisive general improvement in secondary school classes is also expected within the next five years. The White Paper includes a useful summary of progress under the Education Act of 1944.

\title{
THE COUNCIL FOR SCIENCE AND TECHNOLOGY OF WESTERN GERMANY
}

\begin{abstract}
$\mathrm{A}^{\mathrm{N}}$
$\mathrm{N}$ important event during the past year was the foundation of the Wissenschaftrat (Council for Seience and Technology) in Western Germany. It was constituted on February 8 with the Federal President himself taking the chair, following a proposal by the president of the German Research Association (D.F.G.), Prof. Hess. Previously, at its annual general meeting, the Industrial Donors' Association had already welcomed the idea and stood squarely behind it from the outset. The tasks of this new body are as interesting from a purely practical as they are from an idealistic point of view. Just as interesting is its composition, reflecting all sections of academic, public and industrial life, with members who may be expected to take a large and important share in research, university teaching and training, and the application of pure and applied research in industry and commerce. The academic element, as is traditional in Germany in such matters, is in the majority-sixteen professors, all prominent nominees of the German Research Association, the Max Planck Society and the Committee of German Vice-Chancellors (Rektorenkonferenz). In addition to this academic core, the Federal and Land Governments delegate jointly six members, and the Federal Government alone six further leading Civil servants. The latter represent the Ministries of the Interior, Finance, Economics, Food, Transport and include a Secretary of State from the Ministry for Atomic Energy and Waterpower. Also the Länder, the highest education authorities, including universities, are themselves represented at ministerial level, by
\end{abstract}

one delegate each, including Berlin, thus adding nine members. This adds up to thirty-seven, to which the industrialists as sponsors and donors (Stifterverband für die deutsche Wissenschaft) also send their honorary president and curator and six further members.

These forty-five men forming the new Council are thus a significant mixture of prominent personalities and well qualified, it would seem, to deal with their brief. This was summarized in the Bulletin Wirtschaft and Wissenschaft, published in the spring of 1958 :

(1) The reflexion to the outside world of the unity and equality of all science, that is, of the equal importance of research, teaching and training in Germany. This Council could be described as the 'scientific conscience of the nation'.

(2) The Council will have to assess and determine the total requirements of the three tasks, research, teaching, and training, covering the whole federal area.

(3) The Council has to hold a watching brief over a proper flow of young men of promise from university institutions, industry, public life, into positions of responsibility and leadership.

(4) Reforms and developments have to be taken care of, with regard to all three aspects mentioned above, and the financial implications to be worked out in collaboration with the Ministry of Finance.

(5) A key to apportioning financial liabilities among Federal and Land governments has to be found, possibly on a quinquennial basis. (The latter point recalls the five-year period in the fiscal commitments 
of the Treasury in Britain, through the University Grants Committee, and it is not improbable that the German suggestion was influenced by the British example. There is ample evidence that the latter was carefully studied.)

(6) The Council will have to smooth out inequalities and co-ordinate measures taken by the central and local governments (Länder, cities and districts), as regards the promotion of interest in science and research.

(7) Finally, it will be the Council's duty to scrutinize a proposal to create a central agency for the promotion of science, scholarship and research, under a federal ministry.

This is only a brief statement of the main aims for which this Council was called into being. Conditions for its proper functioning will, of course, be :

(1) The provision of adequate grants for supraregional research institutions and projects, from the central Government and the land authorities, inasmuch as the latter cannot adequately finance them.

(2) The willingness of Länder governments to supplement federal funds in finaneing certain regional institutions.

(3) The readiness of industrial and commercial organizations to give larger sums than hitherto for the general promotion of science and for scholarships, over and above those which benefit industry directly.

(4) Parliament will have to strengthen and support the Council by accepting its advice and legislating in the light of this advice. The Council should in time achieve considerable public importance, comparable to that of the University Grants Committee.

(5) Finally, the Council should devise broad reforms for staff-student relations in institutions of higher education, for only this can ensure the vigilance necessary for 'talent-spotting' in the future.

Perhaps the most important of these points is Parliament's job of budgeting for developments in science, scholarship and technology. The first step has already been taken: annual returns have been abandoned in favour of five-year plans. A carry-over of unspent funds must obviously be permissible. Altogether, a generous, non-bureaucratic attitude seems to have been emphasized from the outset, as befits a body composed of representatives drawn from so many sources.

All members of this new Council are aware that they have to make up a good deal of lost time and, for the sake of their country's great tradition in research and scholarship, they are anxious to regain a now leading place in international science.

J. Horne

\section{PHOSPHATES AND ORGANIC SUBSTANCES IN NITROGEN DEFICIENCY}

$\mathrm{T}$ HE International Assoeiation for Research on Phosphates, with its headquarters at 28 rue Saint-Dominique, Paris VIIe, held its third congress at Biarritz during October 21-24. Approximately one hundred scientists and chemical engineers from twenty-three countries attended the Congress, which which was on the greater utilization of phosphates.

Communications on mining phosphate rocks, their solubility, residual effects in soils, influence in plant growth and value when incorporated with organic substances were read and discussed.

Drs. L. Schmitt (Darmstadt, president of the Association), F. Van der Paauw (Gröningen), F. Scheffer (Göttingen), L. Gisiger (Liebefeld, Switzerland), Ed. Hofman (Weihenstephan, Germany), L. Wiklander (Uppsala) and G. Barbier (Versailles) considered different aspects of the solubility of natural rock phosphates when added to soils and the phosphates present in soils under various conditions.

Drs. J. Cuzin (Paris, secretary of the Association), A. Fardy (Athens), Mme. Bireska (Warsaw), Drs. S. Nicolic (Belgrade), K. Nehring (Rostock) and M. Homes (Brussels) presented their observations on drop growth fertilized by different sparingly soluble calcium phosphates and phosphate rocks. Dr. $O$. Arrhenius (Grödinge, Sweden) reported a favourable effect on growth of trees when fertilized by powdered rock phosphates at the rate of one $\mathrm{kgm}$. per tree.

All over the world there is a tendency towards a greater utilization of basic slag, phosphate rocks and strongly heated phosphate rocks instead of superphosphate and other soluble phosphates. This is certainly good for permanent agriculture, because the basic calcium phosphates leave a greater residual effect in soils and decrease the leaching of lime from the land. Dr. G. W. Cooke (Rothamsted) reported a more marked gain in the phosphate status of land when treated with bone meal than when superphosphate was utilized in the Saxmundham experiments over fifty-six years. It is of interest to note in this connexion that Dr. S. Nordengren (Landskrona, Sweden), the leader of the superphosphate industry in Sweden, is considering the manufacture of under-acidulated superphosphate and triple superphosphates for the market.

Interesting experiments on the solubilization of rock phosphates by the action of soil micro-organisms were described by Drs. L. Meyer and Eva Köning (Hohenheim-Stuttgart) and Dr. J. Pochon and Mlle. A. Roche (Pasteur Institute, Paris).

Dr. N. R. Dhar (Allahabad) discussed the augmentation of atmospheric nitrogen fixation in soils by incorporating different phosphates, with organic substances like green manure, farmyard manure, straw, municipal waste, leaves, grass sods, sawdust, legumes, or finely divided coal dust ploughed into the soil. He also reported that when basic slags, phos. phate rocks or superphosphates are added to these organic substances during the process of composting, there is more fixation of atmospheric nitrogen in light than in the dark, and that the total nitrogen contents of the phosphated composts vary from $1 \cdot 6$ to $2 \cdot 4$ per cent as against $0 \cdot 6-1$ per cent present in the Indore composts of Howard. In this connexion it is interesting to record that Dr. L. Borasio (Vercelli, Italy) obtained good results in rice cultivation with a mixture of powdered rock phosphate and farmyard manure. Similar observations were described by Drs. E. Bottini (Turin) and A. Zeller (Vienna). 